\title{
THE EFFECT OF AUDIT KNOWLEDGE, AUDIT DOCUMENT COMPLEXITY AND AUDITOR EXPERIENCE TOWARDS AUDIT JUDGEMENT OF INTERNAL AUDITOR IN WEST ACEH INSPECTORATE OFFICE, INDONESIA
}

\author{
WARDAH MUHARRIYANTI SIREGAR ${ }^{1}$, JUMADIL SAPUTRA ${ }^{2 *}$, MURSYIDIN ${ }^{3,4}$ AND ZIKRI \\ MUHAMMAD $^{2}$
}

\author{
${ }^{1}$ Sekolah Tinggi Agama Islam Negeri (STAIN) Teungku Dirundeng, Meulaboh, Indonesia \\ ${ }^{2}$ School of Social and Economic Development, Universiti Malaysia Terengganu, 21030 Kuala Nerus, Malaysia \\ ${ }^{3}$ Faculty of Political and Social Sciences, University of Malikussaleh, 24351 Kota Lhokseumawe, Indonesia \\ ${ }^{4}$ Faculty of Political and Social Sciences, University of Teuku Umar, Meulaboh, Indonesia
}

${ }^{*}$ Corresponding author: jumadil.saputra@umt.edu.my

\begin{abstract}
The audit is a process of overseeing financial reporting and disclosure by evaluating a relatively large amount of alternative information and determining whether it meets accounting standards. Auditors are responsible for issuing audit judgements. The quality of the audit judgement indicates how well the auditors performed their duties. This study examines the effect of audit knowledge, audit document complexity and auditor's experience on the audit judgements of the internal auditor in the Inspectorate office West Aceh, Indonesia. A quantitative analysis through cross-sectional data was performed to achieve the objective of this study. The primary data were collected through questionnaires administered to 40 auditors comprising 28 auditors with structural positions and 12 auditors with functional positions and analysed using descriptive and inferential statistics involving multiple regression analysis using the Statistical Package for Social Sciences-22. The result of this study showed that the audit knowledge, audit document complexity and auditor experience have a significant effect on the audit judgement of the internal auditor in the Inspectorate office West Aceh, Indonesia. Further, this study found that audit knowledge is the most influential factors affecting the audit judgement of the internal auditor.
\end{abstract}

Keywords: Audit Knowledge, Complexity Document Audit, Auditor's Experience, Audit Judgement.

\section{Introduction}

The audit is one part of the oversight. In practice, it consists of seeking information about what is being implemented in an agency which is checked, compared with the criteria set, and approved or rejected to provide recommended corrective measures (Sukriah et al., 2009). In conducting the audit assignment, the auditor should evaluate a relatively large amount of different information to meet the standards of field work i.e. sufficient competent audit evidence to be obtained through inspection, observation, inquiry, and confirmation as a reasonable basis for their opinion on the audited financial statements (Indonesian Accounting Association, 2010).

Audit judgement will direct the auditor to focus on making their best professional judgement (Mala \& Chand, 2015; Nelson \& Tan, 2005). It is a judgement that affects the documentation of evidence and the decisions made based on the auditor's opinion. The quality of this judgement indicates how well the auditor performed his/her duties. An auditor in the audit process provides a professional opinion based on the events of the past, present, and future (Messier, 2003; Shek et al., 2007). The results of the Bureau of Eradication Corruption (BPK) audit showed that the District Government Financial Report (LKPD) in 2014 for the West Aceh district did not function efficiently. The LKPD was found to have weak internal control systems and noncompliance with laws and regulations. This means that the Inspectorate as the unit manager and supervisor of local government processes has not been providing optimal audit judgements which suggest the weakness of the internal government supervisory apparatus (APIP) to assess and detect potential fraud (Prihartini et al., 2015).

An audit judgement is influenced by several factors, such as knowledge audits (Ashton, 1991; Nelson et al., 1995; Tan \& Kao, 1999), the complexity of the document audit (Brooks et al., 2013; Sari, 2016; Stuart \& Prawitt, 2004; Susanti, 2012; Yustrianthe, 2012) and the auditor's experience (Hanjani \& Rahardja, 2014; Pandoyo, 2016; Rahmawati, 2013). The first factor that affects the audit judgement is the auditor's knowledge. The auditor's knowledge is defined as the level of education and training possessed by an auditor that influenced his/her proficiency in carrying out audit work (Masrizal, 2010). The second factor is the complexity of the audit document which refers to a large number of audit documents to be processed by the auditor both in different accounts, and the number or size of the account balance (Nadirsyah et al., 2011). Another factor that may affect the auditor's audit judgement is an experience. Experience is a learning process and increases the development potential of good behaviour from the formal and non-formal or can be defined as a process that brings a person to a better pattern of behaviour (Kolb \& Kolb, 
2009). Referring to the background of the study, we found that numerous authors overlooked internal auditors and did not consider important variables such as auditor knowledge and experience. Therefore, this study tests the effect of knowledge, experience and audit document complexity on the audit judgement of internal auditors in Aceh, Indonesia empirically.

\section{Literature Review Audit Judgement}

An audit judgement is determining the results of the audit opinion regarding the formation of an idea, opinion or estimate of an object, event, status or any other event type (Knapp, 1985). Also, Hogarth \& Einhorn, (1992) interpreted the judgement as a process of understanding the behaviour of the selection decisions. The process of consideration depends on the information which can continuously affect the choices that will be taken by the auditor. Each step in the process of continuous consideration if information influences the judgement.

\section{Audit Knowledge}

Audit work requires professional skills to perform the audit duties. Therefore, the auditor is required to have extensive knowledge about auditing and technical knowledge that must be mastered. The auditor should also have analytical skills as a basis for judgement. The auditor's knowledge of the audit will grow with increasing work experience. The auditing standards issued by the Indonesian Accountant Institution (IAI) and the Government Accounting Standards (SAP) requires the auditor should have sufficient understanding of the internal control systems to plan the audit and determine the nature, timing, and extent of tests to be performed. Auditors must also meet the requirements of staff expertise in carrying out audits (Indonesian Accounting Association, 2010).

\section{Audit Document Complexity}

The complexity of the audit document can occur in several accounts and the number or size of the account balance. According to Nadirsyah et al., (2011), the complexity of the audit can be viewed in two aspects. First, the complexity of that work to be done to complete a job. Second, the complexity of coordination which refers to the amount of coordination or the relationship between the different parts of an organisation is needed to complete a job.

\section{Auditor's Experience}

An auditor's experience refers to his/her experience in examining financial statements, and the amount and duration of work assignment and assessment of the same problems (Masrizal, 2010). Nyoman Ayu Suryandari et al., (2017) reveals that experienced accountants make a better judgement in the duties of a professional accountant rather than an inexperienced examiner. Hence, an auditor's experience as an auditor influences their judgements (Haynes et al., 1998).

\section{Relationship of Audit Knowledge with Audit Judgement}

Knowledge is known as the schema that regulates the long-term memory. The scheme is a prototype that is often used in interpreting individual experience with relevant knowledge (Coulter, 1994). Research shows that differences in knowledge can lead to different judgements in decision-making (Nelson et al., 1995). Coulter (1994) found that knowledge has a significant influence on audit judgement. Auditors with higher education performed better than those with less knowledge. Tan \& Kao (1999) found that the more knowledge an auditor possesses improves their performance. More knowledge means better judgements.

\section{Relationship of Complex Audit Documents with the Audit Judgement}

Complex audit documents are the amount or number of key documents that can be used to manufacture a consideration (Rahmawati, 2013). Audit sample is very useful because the auditor usually does not have specific knowledge about account balances or transactions that need to be tested by the auditor to satisfy the audit objectives. Therefore, the auditor can identify sources of potential data that can be used as proof of the examination. The auditor should consider the validity and reliability of the data, including data collected by the audited entity, the data compiled by the auditors, or data provided by the third party. Nadirsyah et al., (2011); Yustrianthe, (2012) found that the complexity of the document affects the auditor's audit judgement. Praditaningrum \& Januarti, (2012) also found that the complexity of the task influences the audit judgement. The high complexity of audit documents influences the auditor's decision to make a judgement on the audited financial statements.

\section{Relation of Auditor's Experience with Audit Judgement}

Shelton (1999) stated that the experience would reduce the influence of irrelevant information in the auditor's judgement. Experienced auditors (partner in the manager) make judgements regarding the going concern that is not affected by the presence of irrelevant information. The presence of irrelevant information influences auditors who lack experience regarding going concern considerations. Ponemon \& Wendell (1995) explain that an experienced auditor shows the projection error better than the junior auditor. Research suggests that the auditor's experience affects their audit judgement 
(Coulter, 1994; Mala \& Chand, 2015; Rahmawati, 2013; Schafer, 2007). The more experienced an auditor, the better able they are to perform complex duties.

\section{Materials and Methods}

The cross-sectional study is designed to examine the effect of knowledge audits, audit document complexity and auditor's experience (X) on audit judgement (Y). The sample of this study is collected from 40 internal auditors in the West Aceh Inspectorate Office. The primary data is gathered from the questionnaire administered to internal auditors in West Aceh Inspectorate Office and analysed using multiple regression analysis. Before that, the instruments were tested for validity and reliability. The general form of regression formula is presented below:

$$
Y=\alpha+\beta X
$$

Where $X$ is the explanatory variable and $Y$ is the dependent variable. The slope of the line is $\beta$, and $\alpha$ is the intercept (the value of $\mathrm{y}$ when $\mathrm{x}$ is equal to 0 ). In general, such a relationship may not hold for the largely unobserved population of values of the independent and dependent variables; we call the unobserved deviations from the above equation the errors. The relationship between the true (but unobserved) underlying parameters $\alpha$ and $\beta$ and the data points in equation 3.2 a linear regression model.

$$
Y_{i}=\alpha+\beta X_{i}+\varepsilon_{i}
$$

Further, the specification model of regression in this study can be seen as follows:

$$
A D J_{i}=\alpha+\beta_{1} K W A_{i}+\beta_{2} C D A_{i}+\beta_{3} A D E_{i}+\varepsilon_{i}
$$

Where $A D J$ is audit judgement (dependent variable), $K W A$ is knowledge audit, $C D A$ is complexity audit documents, and $A D E$ is auditor's experience (independent variables). The constant is symbolised using $\alpha, \beta 1, \beta 2$, and $\beta 3$ denoted as Regression Coefficients, and $\varepsilon$ represents an error term. Also, using the previous discussion and empirical finding of previous studies, there are three hypotheses proposed in this study:

\section{Results and Discussions The Result of Data Analysis}

This study uses multiple linear regression analysis to achieve the research objectives. Before embarking on the
Ha1: Audit Knowledge has a significant positive effect on audit judgement.

Ha2: Audit Document Complexity has a significant positive effect on audit judgement.

Ha3: Auditor's experience has significant positive effect on audit judgement.

inferential result of the analysis, we present the result of testing validity and reliability measurement scale and descriptive statistics. The Cronbach's alpha measures the measurement scale reliability. It is a measure of internal consistency, that is, how closely related a set of items are as a group (Hair et al., 2010).

Table 1: The Result of Testing the Reliability Measurement Scale

\begin{tabular}{llll}
\hline No & Variable & N-Item & Cronbach's Alpha \\
\hline 1 & Audit Knowledge & 8 & 0.926 \\
2 & Audit document Complexity & 7 & 0.774 \\
3 & Auditor's experience & 6 & 0.832 \\
4 & Audit Judgement & 12 & 0.841 \\
\hline
\end{tabular}

Table 1 shows the value of Cronbach's alpha is higher than 0.70 . It means that the variables used in this study are reliable. The minimum value of Cronbach's alpha is 0.774 , i.e., the audit document complexity and the maximum value of Cronbach's alpha are 0.926 in audit knowledge. The value of the alpha coefficient is more than 0.80 , suggesting that the items have relatively high internal consistency (Hair et al., 2010). Further, a reliability coefficient of Cronbach's alpha of 0.70 or higher is considered "acceptable" in most social science studies. Having that, this study presents the respondent's distribution. The result of demographic respondents can be seen in Table 4.2: 
THE EFFECT OF AUDIT KNOWLEDGE, AUDIT DOCUMENT COMPLEXITY AND AUDITOR EXPERIENCE TOWARDS AUDIT JUDGEMENT OF INTERNAL AUDITOR IN WEST ACEH INSPECTORATE OFFICE, INDONESIA

Table 2: Demographic Profile of Respondents

\begin{tabular}{llcc}
\hline Demography & Category & Frequency & Percent \\
\hline \multirow{2}{*}{ Gender } & Male & 29 & 72.5 \\
& Female & 11 & 27.5 \\
& Senior high school & 4 & 10.0 \\
Education level & Diploma & 3 & 7.5 \\
& Bachelor & 30 & 75.5 \\
Work experience & Postgraduate (Master and PhD) & 3 & 7.5 \\
The number of duties & 3 years and above & 40 & 100.0 \\
\hline
\end{tabular}

Table 2 reveals that the majority of respondent is male with $72.5 \%$ and females are $27.5 \%$. The education level of respondents is divided into four categories, i.e. senior high school, diploma, undergraduate (Bachelor) and postgraduate (Master and $\mathrm{PhD}$ ). Most of the auditors who participated in this study have a bachelor degree (30 respondents), and only 25 respondents have a senior high school, diploma and postgraduate. Also, to achieve the objectives of this study, we prove the result of hypotheses testing as seen in Table-3 below:

Table 3: Hypotheses Testing

\begin{tabular}{|c|c|c|c|c|c|}
\hline \multirow{2}{*}{ Variable (s) } & \multicolumn{2}{|c|}{ Unstandardised Coefficients } & \multirow{2}{*}{$\begin{array}{c}\begin{array}{c}\text { Standardised } \\
\text { Coefficients }\end{array} \\
\text { Beta }\end{array}$} & \multirow{2}{*}{ t-stats } & \multirow{2}{*}{ Sig. } \\
\hline & $\mathrm{B}$ & $\begin{array}{l}\text { Std. } \\
\text { Error }\end{array}$ & & & \\
\hline (Constant) & 0.177 & 0.431 & & 0.272 & 0.787 \\
\hline Audit Knowledge & 0.301 & 0.064 & 0.462 & 4.744 & 0.000 \\
\hline Audit document Complexity & 0.359 & 0.116 & 0.328 & 3.104 & 0.004 \\
\hline Auditor's experience & 0.261 & 0.103 & 0.276 & 2.537 & 0.016 \\
\hline R Square & 0.741 & & F - Stats & 34.310 & \\
\hline Adjusted R Square & 0.719 & & df & 36 & \\
\hline Std. Error of the Estimate & 0.213 & & Sig. & 0.000 & \\
\hline
\end{tabular}

Dependent variable: Audit Judgement

Table 3 displays the result of hypotheses testing. Based on the data analysis, this study found that the value of $\mathrm{R}$ square is 0.741 . It means that the percentage of the response variable which consists of audit knowledge, audit document complexity, auditor's experience is explained by a linear model on the dependent variable that is audit judgement. In general, the higher the value of R-squared, the better the model fits the data. Next, using the value of F-stats, the analysis indicates that the three independent variables consisting of the audit knowledge, audit document complexity, auditor's experience affect the audit judgement with the F-stats of 34.310 and significant at the level of $0.01(1 \%)$.

In addition, to test hypotheses partially, this study uses the result of multiple regression. It aims to find which variable significant influences the audit judgement. The table above indicates that audit knowledge has significant positive relationships with the audit judgement. The value of beta is equal to 0.462 and significant at the level of $0.01(1 \%)$. It means that by assuming the audit knowledge increases as much as $1 \%$,

$$
A D J_{i}=0.117+0.301 K W A_{i}+0.359 C D A_{i}+0.261 A D E_{i}
$$

then the value of audit judgement is $46.2 \%$. Thus, the alternative hypothesis (H1) is accepted. The audit document complexity has significant positive relationships with the audit judgement. The value of beta is equal to 0.328 and significant at the level of $0.01(1 \%)$. It means that by assuming the audit knowledge increases as much as $1 \%$, then the value of audit judgement is $32.8 \%$. Thus, the alternative hypothesis (H2) is accepted.

The auditor's experience has a significant positive relationship with the audit judgement. The value of beta is equal to 0.276 and significant at the level of $0.01(1 \%)$. It means that by assuming the audit knowledge increases as much as $1 \%$, then the value of the audit judgement is $27.6 \%$. Thus, the alternative hypothesis (H3) is accepted. Besides that, using the multiple regression equation in Equation 3.3, the result of this study can be written as follows: 


\section{Discussions}

The audit judgement is a process of understanding the selection decisions behaviour which depends on the information that affects the final decision of the auditor (Hogarth \& Einhorn, 1992). Every stage in the audit process part of the auditor's consideration and decision. Numerous factors influence the audit judgement i.e., audit knowledge, audit document complexity and auditor's experience (Coulter, 1994; Nelson et al., 1995; Praditaningrum \& Januarti, 2012; Schafer, 2007; Shelton, 1999; Tan \& Kao, 1999; Yustrianthe, 2012).

Using the result of data analysis, this study found that audit knowledge has a significant positive effect and is the most influential factor influencing the audit judgement. Similar findings were reported by Coulter (1994) who found that the audit knowledge has a significant influence on audit judgement. He adds that more knowledgeable auditors perform better than those with less knowledge. Further, a similar point was made by Tan \& Kao (1999) who stated that knowledgeable auditors have improved performance. It means that more knowledge will result in better judgements. Besides the audit knowledge, another important factor which has a significant relationship with the audit judgement is audit document complexity. Yustrianthe (2012) defines the audit documents complexity as the number of key documents used by auditors as input or information to make audit judgements.

Further, through the result of data analysis in this study, we found that the audit documents complexity has a significant positive effect on audit judgement. This finding in line with Nadirsyah et al., 2011; Yustrianthe (2012) who also found that the complexity of the audit document has a positive effect on audit judgement. Highly complex audit documents influence the auditor's judgement on the audited financial statements. This is because the audit documents are extremely useful to auditors who usually do not have knowledge about account balances or transactions to identify the potential sources of data that can be used as evidence for the investigation. We also found that the auditor's experience shows a significant positive relationship with the audit judgement. This finding is similar to the results obtained by Shelton (1999), who found that the auditor's experience could be reducing irrelevant information in audit judgement. Additional support for this finding comes from Ponemon \& Wendell (1995) who found that an experienced auditor could minimise errors more than junior auditors. In other words, more experienced auditors could perform better in complex duties compared to less experienced auditors.
Based on the results of data analysis and discussion, we can conclude that the audit knowledge, audit document complexity and auditor's experience have significant positive effects on the audit judgement. Further, the audit knowledge is the most influential factor in the audit judgement. The several limitations in this study are; (i) The results of this study refer only to auditors working in the Inspectorate so that the results cannot be generalised to the auditors who work as public accountants. (ii) This study samples only 40 auditors. For further research, we suggest increasing the number of respondents and include other variables that affect audit judgement such as moral considerations and compliance. This study expects the findings can be useful to internal auditors of the Inspectorate Office in West Aceh. The government should ensure the auditors have good knowledge regarding the audit process and procedure and understand the complexity of the documents to be audited and are experienced. Further, the West Aceh Government may consider the capacity of auditors for better audit quality and audit judgements.

\section{References}

Ashton, A. H. 1991. Experience and Error Frequency Knowledge as Potential Determinants of Audit Expertise. The Accounting Review VO - 66.

Brooks, L. Z., Cheng, C. S. A., \& Reichelt, K. J. 2013. Audit Firm Tenure and Audit Quality: Evidence from U.S. Firms. SSRN. https://doi.org/10.2139/ssrn.2201350

Coulter, J. M. 1994. The effects of audit experience and probability knowledge on auditors' use of heuristics in judgments under uncertainty. Dissertation Abstracts International Section A: Humanities and Social Sciences.

Hair, J. F., Black, W. C. W. C., Babin, B. J., Anderson, R. E., Babin, B. J., \& Black, W. C. W. C. 2010. Multivariate data analysis: A global perspective. Vectors.

https://doi.org/10.1016/j.ijpharm.2011.02.019

Hanjani, A., \& Rahardja. 2014. Effects of Auditor Ethics, Auditor Experience, FEE Audit, and Audit Motivation on Audit Quality (Study of KAP Auditors in Semarang). Diponegoro Journal of Accounting. https://doi.org/10.1016/j.exer.2014.10.014\rS00144835(14)00284-X [pii]

Haynes, C. M., Jenkins, J. G., \& Nutt, S. R. 1998. The relationship between client advocacy and audit experience: An exploratory analysis. Auditing. https://doi.org/DOI 10.1016/j.landusepol.2008.10.016

Hogarth, R. M., \& Einhorn, H. J. 1992. Order effects in 
belief updating: The belief-adjustment model. Cognitive Psychology. https://doi.org/10.1016/00100285(92)90002-J

INDONESIAN ACCOUNTING ASSOCIATION. 2010. Professional Standar of Public Accountant. Jakarta, Indonesia: Salemba Empat Publishing.

KNAPP, M. 1985. Audit Conflit: An Empirical Study of the Perceived Ability of Auditors to Resist Management Pressure. The Accounting Review. https://doi.org/10.2307/246786

Kolb, A. Y., \& Kolb, D. A. 2009. Experiential learning theory: A dynamic, holistic approach to management learning, education and development. SAGE Handbook of Management Learning, Education and Development.

Mala, R., \& Chand, P. 2015. Judgment and decisionmaking research in auditing and accounting: Future research implications of person, task, and environment perspective. Accounting Perspectives. https://doi.org/10.1111/1911-3838.12040

Masrizal. 2010. The influence of Audit Experience and Knowledge on Detection of Findings of Losses (Study at the Aceh Inspectorate Auditor). Jurnal Telaah \& Riset Akuntansi.

Messier, W. F. 2003. Auditing and Assurance: A Systematic Approach. McGraw-Hill. https://doi.org/10.3386/w11785

Nadirsyah, Indriani, M., \& Usman, I. 2011. Effect of Audit Time Budget, Complexity of Audit Documents and Auditor's Experience on Consideration of Audit Sampling at the Financial Examination Agency (Bpk) of the Republic of Indonesia Representative of Aceh Province. Jurnal Telaah \& Riset Akuntansi.

Nelson, M., \& Tan, H. T. 2005. Judgment and decision making research in auditing: A task, person, and interpersonal interaction perspective. In Auditing. https://doi.org/10.2139/ssrn.761706

Nelson, M. W., Libby, R., \& Bonner, S. E. 1995. Knowledge Structure and the Estimation of Conditional Probabilities in Audit Planning. The Accounting Review.

Nyoman Ayu Suryandari, N., Mahasaraswati Denpasar Bali, U., \& Anik Yuesti, I. 2017. Profesional Scepticism and Auditors Ability to Detect Fraud Based on Workloads and Characteristics of Auditors. Scientific Research Journal (SCIRJ).

Pandoyo. 2016. The Effect Of Auditor Competence, Independence, Audit Experience, Organizational
Culture And Leadership Against Auditor Professionalism And Its Implication On Audit Quality. International Journal of Advanced Research.

Ponemon, L. A., \& Wendell, J. P. 1995. Judgmental Versus Random Sampling in Auditing - an Experimental Investigation. Auditing-a Journal of Practice \& Theory.

Praditaningrum, A., \& Januarti, I. 2012. Analysis of the factors that influence audit judgment (Study on the Republic of Indonesia BPK Representative of Central Java Province). Retrieved from http://eprints.undip.ac.id/35528/

Prihartini, A. K., Sulindawati, L. G. E., \& Darmawan, N. A. S. 2015. Effect of Competence, Independence, Objectivity, Integrity and Accountability on Audit Quality in Local Government (Empirical Study at 5 Inspectorate Offices of Bali Province). E-Journal S1 Ak Universitas Pendidikan Ganesha.

Rahmawati, Y. 2013. Effects of Audit Risk, Audit Experience, and Audit Complexity on Auditor Considerations (Study of the BPK-RI Representative Office of the Aceh Representative). Unsyiah.

Sari, I. P. 2016. Gender Influence, Obedience Pressure, Task Complexity, Auditor Experience, Auditor Knowledge and Audit Document Complexity Against Audit Judgment (Empirical Study at the Central Indonesian Supreme Audit Agency). Jurnal Online Mahasiswa Fakultas Ekonomi Universitas Riau, 3(1), 2008-2022.

Schafer, B. A. 2007. Accountability and Affect in Auditor Judgment. SSRN. https://doi.org/10.2139/ssrn.1010762

Shek, W. Y., Cheung, C. F., Lee, W. B., \& Chong, Y. Y. 2007. Systematic Knowledge Auditing: A Case Study in a Power Utility Company. Journal of Information \& Knowledge Management. https://doi.org/10.1142/S0219649207001809

Shelton, S. W. 1999. The effect of experience on the use of irrelevant evidence in auditor judgment. Accounting Review. https://doi.org/10.2308/accr.1999.74.2.217

Stuart, I., \& Prawitt, D. F. 2004. The Influence of Audit Structure on Auditors' Performance in High and Low Complexity Task Settings. SSRN. https://doi.org/10.2139/ssrn.569871

Sukriah, I., Akram, \& Inapty, B. A. 2009. The Influence of Work Experience, Independence, Objectivity, Integrity and Competence on Quality of Audit Decision. Sna. https://doi.org/10.1017/CBO9781107415324.004 
SSRN. https://doi.org/10.2139/ssrn.147869

Susanti, R. 2012. The Influence of Moral Considerations, Compliance Pressure, and Complexity of tasks on the Aceh Inspectorate Audit Judgment. Unsyiah.

Tan, H.-T., \& Kao, A. 1999. Accountability Effects on Auditors' Performance: Influence of Knowledge, Problem-Solving Ability, and Task Complexity.
Yustrianthe, R. H. 2012. Several Factors Affecting

Government Audit Auditor Judgment. Jurnal Dinamika

Akuntansi.

https://doi.org/10.1017/CBO9781107415324.004 